\title{
LEITURA DE IMAGENS EM ARTE: UM OLHAR PARA A EDUCAÇÃO DE SURDOS
}

\author{
Ivan Jeferson Kappaun ${ }^{1}$ \\ Janete Inês Müller ${ }^{2}$ \\ Daiane Kipper ${ }^{3}$ \\ Adriana da Silva Thoma ${ }^{4}$
}

\section{Resumo}

Este trabalho propõe uma reflexão sobre a leitura de imagens realizada por sujeitos surdos que estudam em uma turma comum do $2^{\circ}$ Ano do Ensino Médio, em uma escola da rede pública de Santa Cruz do Sul/RS. Na articulação aos Estudos Surdos e à Arte-Educação,

\footnotetext{
${ }^{1}$ Licenciado e bacharel em Artes Visuais (UFSM); especialista em Educação Especial e em Arte-Educação (UNIASSELVI). Docente nas redes municipal e estadual de Educação Básica - Santa Cruz do Sul/RS. Endereço: Avenida Independência, 1656, Avenida, Santa Cruz do Sul, RS, Brasil. E-mail: ivankappaun@yahoo.com.br

${ }^{2}$ Graduada em Letras (UNISC); especialista em Língua Brasileira de Sinais (UNIASSELVI); Mestre e Doutoranda em Educação pela Universidade Federal do Rio Grande do Sul (UFRGS). Docente no Instituto Federal de Educação, Ciência e Tecnologia Farroupilha - Câmpus São Vicente do Sul/RS. Endereço: Rua Lauro Elemar Hansen, 456, Renascença, Santa Cruz do Sul, RS, Brasil. E-mail: janeteim@ hotmail.com.

${ }^{3}$ Licenciada em Matemática (ULBRA); especialista em Educação Especial (UNIASSELVI) e em Mídias na Educação (UFSM). Mestre em Educação (UNISC). Docente nas redes municipal e estadual de Educação Básica - Santa Cruz do Sul/RS. Endereço: Avenida Independência, 1656, Avenida, Santa Cruz do Sul, RS, Brasil. Email: daianekipper@hotmail.com

${ }^{4}$ Graduada em Educação Especial pela Universidade Federal de Santa Maria (UFSM, 1994), Mestre em Educação pela Universidade Federal do Rio Grande do Sul (UFRGS, 1997) e Doutora em Educação também pela UFRGS (2002). Atualmente é professora Adjunto IV da UFRGS, atuando no Departamento de Estudos Especializados da Faculdade de Educação (DEE/FACED) e no Programa de Pós Graduação em Educação (PPGEDU). Coordenadora do Grupo de Pesquisas SINAIS: Sujeitos, Inclusão, Narrativas, Identidades e Subjetividades. Integrante do Núcleo de Estudos sobre Currículo, Cultura e Sociedade (NECCSO/UFRGS) e do Grupo Interinstitucional de Pesquisa em Educação de Surdos (GIPES). Desenvolve e orienta pesquisas no campo dos Estudos Surdos e Estudos Culturais em Educação, principalmente nos seguintes temas: educação de surdos, educação especial, inclusão escolar, produção de identidades e diferença na educação e avaliação na educação de surdos. Endereço: Av. Paulo Gama, $\mathrm{s} / \mathrm{n}^{\circ}, \quad$ prédio 12.201, $7^{\circ}$ andar 90046-900 - Porto Alegre/RS, Brasil. Contato: asthoma@terra.com.br.
} 
problematizam-se as implicações da experiência visual surda na educação escolar, tendo em vista a observação de uma atividade prática, em que se atribui significado a imagens artísticas por meio da 'Proposta Triangular do Ensino de Arte' (BARBOSA, 1991). Desenvolvida na disciplina de Arte e mediada por tradutores e intérpretes de língua de sinais (TILS), a atividade realizada oportunizou a aproximação dos alunos ao objeto imagético e seu contexto. Considerando-se as identidades surdas, evidencia-se um processo de leitura de imagens que toma como base a visualidade e as experiências singulares de cada sujeito na construção de significados. Em arte e na educação de surdos, a linguagem visual assume centralidade.

Palavras-chave: Surdos; Leitura de imagens; Linguagem visual; Arte-Educação; Estudos Surdos

\section{UMA PROPOSIÇÃO}

A arte oferece a possibilidade de o espectador construir uma significação para uma obra, baseado em suas experiências e por meio das emoções despertadas. Podemos afirmar que a obra alcançará maior amplitude quando o público interagir com a mesma, processo esse que se reinicia toda vez que alguém propõe outra aproximação ao trabalho artístico. Com o intuito de instigar a reflexão, o ensino de arte vale-se de obras que são próximas às pessoas, ainda que estas não estejam habituadas a pensar sobre as mesmas. Embora se discuta o uso de recursos cotidianos na aproximação do público à arte produzida atualmente, o uso de elementos comuns ou banais em arte ainda causa estranhamento; e é nesse estranhamento que residem as interrogações, também servindo como molas propulsoras para o processo reflexivo aqui em discussão.

Em geral, estamos expostos a imagens através de variados artefatos culturais e cada sujeito será interpelado ${ }^{5}$ por eles de acordo com as suas experiências. No caso do sujeito surdo, uma educação do olhar considera-se mais desenvolvida em virtude do uso recorrente da percepção visual; logo, entende-se que os surdos tenham desenvolvida uma maior sensibilidade no que se refere à percepção da linguagem visual. De acordo com Strobel

\footnotetext{
${ }^{5}$ Interpelar é o processo que "ocorre quando um enunciado penetra na dobra do sujeito e se conecta produtivamente com outros discursos que ali já estavam” (Veiga-Neto, 2000, p. 58).
} 
(2009), o sujeito surdo percebe o mundo através dos olhos e, nessa experiência visual, utiliza a visão como meio de comunicação. Por isso, importa refletir sobre a cultura surda, a língua de sinais, os modos diferentes de ser, de expressar e de conhecer o mundo.

Concordando com Skliar,

[..] a surdez é uma experiência visual [...] e isso significa que todos os mecanismos de processamento da informação, e todas as formas de compreender o universo em seu entorno, se constroem como experiência visual. Não é possível aceitar, de forma alguma, o visual da língua de sinais e disciplinar a mente e o corpo das crianças surdas como sujeitos que vivem uma experiência auditiva. (SKLIAR, 2010, p. 28).

É nesse sentido que esta investigação possibilita conhecer e compreender uma leitura de imagens que toma como base a linguagem visual e as experiências de cada sujeito. $\mathrm{Na}$ articulação aos Estudos Surdos e à Arte-Educação, neste texto, discutem-se as implicações da experiência visual surda na educação escolar, tendo em vista a observação de uma atividade prática em que se atribui significado a imagens artísticas. Desenvolvida na disciplina de Arte $^{6}$ e mediada por tradutores e intérpretes de língua de sinais (TILS), a proposta oportunizou a aproximação dos alunos ao objeto imagético e seu contexto. Em vista da proposta 'Triangular do Ensino de $\mathrm{Arte}^{7}$, e tematizando a leitura de imagem da obra Pink Wall (de Miguel Rio Branco), a atividade aqui analisada foi desenvolvida com estudantes surdos em uma turma comum $^{8}$ do $2^{\circ}$ Ano do Ensino Médio, de uma escola pública de Santa Cruz do Sul/RS.

Esta análise provoca-nos a pensar sobre os processos de ensino e de aprendizagem de surdos, visto que a construção de conhecimento por esses alunos se dá principalmente por meio de recursos visuais. Como proposta pedagógica no componente curricular de Arte, oportunizar aos alunos surdos a expressão de suas percepções e emoções frente a imagens consagradas pela História da Arte, comparando-as a elementos do cotidiano em que vivem, apresenta-se produtivo, inclusive para a formação de cidadãos mais reflexivos e críticos. Além disso, a construção de uma proposta que centraliza a visualidade, permitindo que os sujeitos surdos envolvidos tragam aspectos culturais próprios para a construção de significados a partir de imagens artísticas, caracteriza-se como uma experiência significativa aos estudantes, sendo também potente como objeto de análise neste trabalho.

\footnotetext{
${ }^{6} \mathrm{O}$ termo 'Arte', com inicial maiúscula, é utilizado apenas em substantivos próprios; neste texto, é o caso de componente curricular do Ensino Médio, ou dos campos de saber ‘Arte-Educação' e 'História da Arte'.

${ }^{7}$ Conceito desenvolvido por Barbosa (1991), que será posteriormente aprofundado.

${ }^{8}$ Usa-se o adjetivo 'comum' para referência às escolas ou turmas regulares de ouvintes, nas quais também estudam alunos surdos em situação de inclusão, com ou sem a atuação de tradutor e intérprete de língua de sinais (TILS).
} 
Neste texto, em linhas gerais, apresentamos uma proposição, ou seja, um possível modo de pensar a arte na educação escolar de surdos. Não acreditamos em verdades universais, nem sugerimos a instituição de nossas ideias como únicas e imutáveis; pelo contrário, ao aproximarmos campos teóricos, desafiamo-nos na 'ordem incerta do discurso', desentocamos nosso pensamento e prosseguimos abertos para discordar inclusive do que aqui pensamos. Na seção que desenvolvemos a seguir, apresentamos um diálogo com a ArteEducação, discutindo processos de leitura de imagens.

\section{LEITURA DE IMAGENS: UM DIÁLOGO COM A ARTE-EDUCAÇÃO}

Uma das funções da Arte-Educação diz respeito à mediação entre a arte e o público, pois as obras de arte são materializadas pelos artistas que as produziram, mas se alcançam maior amplitude com a participação do público. Enquanto os artistas ou produtores em arte criam suas obras, também interagem com outras pessoas e o meio social; o público, por sua vez, participa ativamente por meio de seus diferentes modos de ver, analisar, apreciar e gostar das obras. Em geral, a arte e o seu ensino adquirem relevância.

\footnotetext{
Arte não é apenas básico, mas fundamental na educação de um país que se desenvolve. Arte não é enfeite. Arte é cognição, é profissão, é uma forma diferente da palavra para interpretar o mundo, a realidade, o imaginário, e é conteúdo. Como conteúdo, arte representa o melhor trabalho do ser humano (BARBOSA, 1991, p. 04).
}

Frente ao papel da arte na formação dos sujeitos, ela se constitui conteúdo de estudo escolar; assume-se que ela pode ser ensinada e aprendida também na escola, sobretudo na disciplina de Arte. Essa corporificação visa ajudar os alunos na apreensão viva e significativa de noções e habilidades culturais, com noções acerca de produções artísticas pessoais e apreciações estéticas, ou análises mais críticas de trabalhos em diversas modalidades. Logo, há a necessidade de se trabalhar a organização pedagógica das inter-relações artísticas e estéticas junto aos estudantes.

Em vista da multiplicidade de competências que a arte e o seu ensino assumem em nossa vida cotidiana, notam-se mudanças nos seus processos de representação, de modo que a arte passa a ser entendida como importante para o desenvolvimento cognitivo, social e cultural da sociedade. Percebe-se também um grande esforço e consequentes resultados na 
melhoria do ensino de arte nas escolas, em que se buscam encaminhamentos pedagógicos baseados em propostas de estudiosos da área e em experiências escolares bem-sucedidas.

Uma proposta importante para a construção do conhecimento em arte foi sistematizada por Ana Mae Barbosa (1991), denominada 'Proposta Triangular do Ensino de Arte'. Esta propõe que a construção do conhecimento em arte acontece quando há a interseção da experimentação com a codificação e com a informação. Nesse caso, são consideradas questões que envolvem o modo de inter-relacionamento entre a arte e o público, bem como sugere-se que a composição do programa do ensino seja elaborada a partir das três ações básicas e executadas no contato com a arte: ler obras de arte, fazer arte e contextualizar.

A crítica e a estética são fundamentais para ler obras de arte, já que este exercício envolve questionamento, busca, descoberta e o despertar da capacidade crítica dos alunos, bem como compreende o domínio da ação, do desenvolvimento artístico, como, por exemplo, o trabalho de ateliê. Ao contextualizar, opera-se no domínio da História da Arte e de outras áreas de conhecimento, necessárias para determinado programa de ensino. Em relação ao ensino/aprendizagem de arte, a concepção de História da Arte não é linear, mas pretende contextualizar a obra no tempo e explorar suas circunstâncias. Em lugar da preocupação em mostrar a chamada 'evolução' das formas artísticas através do tempo, pretende-se mostrar que a arte não está isolada de nosso cotidiano, de nossa história pessoal; ela é parte integrante de nosso dia a dia. No entanto,

O importante não é ensinar estética, história e crítica da arte, mas desenvolver a capacidade de formular hipóteses, julgar, justificar e contextualizar julgamentos acerca de imagens e de arte. Para isso, usam-se conhecimentos de história, de estética e de crítica de arte (BARBOSA, 1991, p. 64).

Assim, contribuindo com o desenvolvimento dos alunos, os conhecimentos de arte envolvem mais do que conhecimentos estéticos e históricos. Através dela, pode-se desenvolver uma apreensão crítica do contexto, que permite analisar a realidade percebida e desenvolver a capacidade criadora. Como aponta Barbosa (2002), é necessário desconstruir para construir, selecionar, reelaborar partir do conhecimento e modificá-lo de acordo com o contexto e a necessidade. Os processos criadores desenvolvidos pelo trabalho com a arte são cada vez mais indispensáveis para adaptação ao mundo em que vivemos.

Além disso, a arte não pode ser entendida como uma manifestação isolada, pois está intimamente relacionada ao homem. Trata-se de uma criação humana, que surge de uma ação que carrega consigo conceitos estéticos, como a beleza, por exemplo. No entanto, muitos 
outros fatores permeiam a relação entre a arte e o homem e a autenticam, como os sentimentos humanos, as emoções permeadas pela cultura, bem como as vivências, experiências e saberes de cada indivíduo. Como ação humana, a arte pressupõe comunicação, que se dá entre sujeitos e criador. A isso chamamos de fruição, em que está implícita a atividade de leitura, produzida em contextos sócio-históricos e que mobiliza mecanismos linguísticos, psicológicos, sociais, culturais e históricos, resultando na produção de sentido, objeto de desejo da leitura de imagem.

Cabe destacar, ainda, que a arte é comumente associada à beleza e ao sentimento. De fato, não podemos eximir a arte de tal atribuição, visto que um dos propósitos da mesma está relacionada ao despertar das emoções do fruidor. É importante destacar que o prazer estético passa pelo conceito de beleza que, uma vez ligada às emoções, perpassa pelo juízo de gosto. Assim, aquilo que é belo para uma pessoa pode não ser para outra. Não existe um critério universal para classificar o que seria belo ou não, pois as vivências, experiências e culturas dos indivíduos são variáveis e singulares.

Nessa perspectiva, importa considerar que o produto do trabalho do artista é constituído não somente por elementos estéticos, mas também intelectuais, políticos e éticos. Se são tais proposições que tornam a obra uma produção única e inigualável, uma vez entendida como criação humana, a arte pode ser considerada uma produção cultural. A obra carrega consigo o pensamento do artista acerca da sociedade em que está inserido, um espaço de tempo e um contexto social, uma condição de possibilidade para a sua produção. Pensando nisso, é possível aventurar-se por uma experiência denominada 'leitura de imagem'.

A imagem pressupõe comunicação. Qualquer tipo de arte, mesmo abstrata, favorece a comunicação. De acordo com Santaella (2002), para construir uma experiência de leitura da obra de arte, é necessário considerar três importantes fases. A primeira é a disponibilidade contemplativa, em que se olha para a obra com simplicidade, deixando os sentidos perceberem-na, passando pelas cores, linhas e formas. A segunda fase é a observação atenta da comunicabilidade da pintura, em se apresenta algo singular e único. Por fim, a terceira fase contempla a generalização do específico dentro da classe a que pertence.

Não há uma receita ou uma fórmula para ler imagens. Para estabelecer uma aproximação com a complexidade da imagem, Oliveira (2005), em sua obra Imagem também se lê, sugere alguns passos para a construção da experiência estética. Segundo ela, inicialmente, convém identificar a estrutura da imagem, observando horizontais, verticais, 
diagonais, formas geométricas e ângulos, ou seja, os elementos que sustentam a composição visual da imagem. Na sequência, parte-se para os elementos constitutivos da mesma, que são linhas, pontos, cores, planos, formas, luz, dimensão, volume, textura, bem como a articulação entre esses elementos, chamados de procedimentos relacionais. Como terceira etapa, Oliveira (2005) sugere que se observe como estão organizados os elementos no texto estético que, uma vez concluído pelo criador, assume voz própria.

Desse modo, o leitor ficaria dispensado de pesquisar sobre a história e o contexto do autor da imagem, considerando, assim, as práticas não-discursivas presentes na própria obra. É na relação entre elementos apresentados na imagem que o leitor vai construindo novos conhecimentos e significações. Por isso, há a importância de observar minuciosamente a imagem, resgatando os pontos relevantes e os relacionando, de modo a se construir uma rede discursiva por meio de procedimentos significantes.

Uma contribuição importante para a leitura de imagens advém de Armindo Trevisan (1990), que aponta algumas vias de acesso à obra e à leitura da mesma, as quais foram também experienciadas nas aulas de Arte aqui analisadas. De acordo com o autor, artista e obra reclamam-se; assim, a obra nunca é alheia ou isolada, mas um reflexo do íntimo do artista, bem como do contexto social em que foi criada. Com esse princípio, tem-se a primeira via de acesso para o processo de leitura de imagem de uma obra de arte, que é a leitura biográfico-intencional. Nesta, a história do artista oferece subsídios para a leitura de sua obra, como, por exemplo, os cadernos de Leonardo da Vinci e as cartas de Van Gogh.

Outro exemplo dessa primeira via de acesso pode ser percebido através do artista espanhol Francisco de Goya, que foi acometido por uma doença que resultou em surdez profunda, quando contava com 47 anos. Na época, o artista era o retratista mais solicitado e fora indicado como pintor da corte por Carlos IV, da Espanha. A surdez exerceu inegável influência sobre a obra do artista, tanto em aspectos cromáticos quanto à temática e qualidade das obras. Na fase final da vida, Goya cobriu as paredes de sua casa, a Quinta del Sordo, com o que se conhece como as Pinturas Negras (quadros que perderam tanto a cor quanto a alegria). Começaram a aparecer situações macabras e repugnantes em relação à vida. Séries de gravuras - como Caprichos e Desastres da Guerra - revelam um artista perturbado e reflexivo sobre os vícios e crueldades do ser humano. Aqui, não somente a surdez, mas também a visão política e social do artista influenciou em seu processo de criação.

A segunda via de acesso apontada por Trevisan é a leitura cronológico-estilística. "Parece evidente que os artistas são influenciados pelas ideias de seu tempo, em especial, por 
seus modos de ver. À guisa de introdução, recordemos que, durante muito tempo, eles aprendiam a pintar ou esculpir, ou a fazer qualquer tipo de arte, sob a direção de mestres." (TREVISAN, 1990, p. 152). De fato, não é incomum na História da Arte encontrarmos artistas que foram fortemente influenciados por seus mestres. No entanto, cabe ressaltar que o foco de atenção deve ser direcionado para o artista e sua obra, e não para estilos, movimentos ou tendências. Os mesmos devem ser considerados como hipóteses de análise, com o intuito de facilitar a investigação.

A terceira via de acesso indicada por Trevisan é a leitura formal, que vai ao encontro de que foi proposto por Oliveira (2005). Aqui, o foco é a obra em si e sua estrutura formal. O objeto artístico é constituído pela organização de diversos elementos: cor, linha, textura, planos, volumes, espaço, luz, sombra, tema e movimento. Uma vez subordinados ao conjunto, tais elementos produzem uma única forma: a da obra. Em síntese, toda obra de arte possui uma forma de organizar os elementos ao dispor do artista, para expressar seus sentimentos, a qual é produzida consciente ou inconscientemente. Ainda que a leitura formal seja bem desenvolvida, traz consigo elementos de outras leituras, tornando inseparáveis os elementos não-formais que também compõem a obra.

Com isso, chega-se à quarta via de acesso: a leitura iconográfica. Esta é importante para a compreensão da obra de arte, visto que adentra o campo do tema abordado pelo artista. Assim, cabe distinguir os dois níveis temáticos, ou de significado, para a compreensão iconográfica da imagem. O primeiro é apreendido pela identificação de certas configurações de linhas e cores, por exemplo; e pela percepção de referências expressionais, como o caráter pesaroso de uma pose, ou a atmosfera pacífica e caseira de um interior. Já o segundo nível prevê que a apreensão se dê pela percepção de que a figura de uma mulher com um pêssego na mão é a personificação da veracidade, que um grupo de figuras sentadas em torno de uma mesa com certa disposição e pose representa a 'Última Ceia', por exemplo. Assim, ligamos os motivos artísticos e composições aos assuntos e conceitos que devem, por sua vez, ser previamente conhecidos.

Por fim, Trevisan (1990) propõe a quinta via de acesso: a leitura iconológica. Esta se configura como uma análise muito mais aprofundada que a proposta pela iconografia. Tal leitura visa definir a concepção de mundo que se reflete em uma determinada manifestação artística e a atitude que o homem adota perante a realidade na qual está inserido 
(independentemente de espaço e tempo), não somente quando pretende representá-la, mas também quando reflete ou age sobre ela.

Portanto, observa-se que vários são os caminhos ou vias de acesso à obra, bem como as estratégias que podem ser adotadas para a realização da leitura de imagens. Vale ressaltar que não há uma regra de aproximação com o objeto artístico, muito menos quer-se sugerir tal proposta. O que há são possibilidades que podem ser utilizadas de acordo com os elementos que o objeto artístico ou a imagem oferecem. Na atividade prática desenvolvida com alunos em aulas de Arte, descrita na próxima seção e que constitui objeto de análise neste texto, foram utilizados os passos apontados por Oliveira (2005); as vias de acesso formal e iconográfica, sugeridas por Trevisan (1990); as vias de acesso biográfico-intencional e a cronológico-estilístico para objetos artísticos.

\section{ATIVIDADE PRÁTICA NA EDUCAÇÃO DE SURDOS}

Problematizar as implicações da experiência visual surda na educação escolar, tendo em vista a observação de uma atividade prática de leitura de imagens, requer algumas descrições ao longo desta seção, as quais contemplam a proposta realizada em aulas de Arte, em uma escola pública de Santa Cruz do Sul/RS. Nesse caso, importa considerar que a turma comum de $2^{\circ}$ Ano de Ensino Médio, em que foi realizada atividade prática aqui analisada, é composta de estudantes surdos e ouvintes. Os docentes ministram as aulas em língua portuguesa, com a presença de tradutor e intérprete de língua de sinais (TILS), visando garantir a acessibilidade na comunicação.

Para pensar a educação de surdos, é fundamental compreender que as práticas pedagógicas escolares modificaram-se ao longo dos tempos. Não pretendemos, neste texto, fazer uma retomada histórica e a caracterização de modelos educacionais como o Oralismo e a Comunicação Total. Também não objetivamos discutir os processos de inclusão de estudantes surdos em turmas comuns das escolas, visto que esse debate, para além de posicionamentos favoráveis ou contrários, implica uma análise das condições de possibilidades para a escolarização de surdos. Inevitavelmente, porém, cabe refletir sobre a proposta de educação escolar bilíngue, reivindicada pelas comunidades surdas e legalmente garantida, a qual é constituída de diferentes modos nas instituições escolares, inclusive na Escola em que foi realizada a atividade prática que aqui apresentamos. 
Conhecimentos e tendências vinculadas à proposta de educação bilíngue são apontados como propositivos e significativos, tanto é que a temática tem sido incorporada às agendas de políticas públicas brasileiras. De acordo com Karnopp (2012), a educação bilíngue inclui, no mínimo, duas grandes áreas, a Educação e a Linguística, aproximando o bilinguismo à condição de uso ou de contextos de uso de duas ou mais línguas em contato, sem se caracterizar como uma condição inerente e permanente do sujeito. Na educação de surdos, o bilinguismo, pode ser compreendido como a habilidade de usar a Língua Brasileira de Sinais (Libras), de modalidade visual-espacial, e a língua portuguesa (como segunda língua, na modalidade escrita), em diferentes graus de competência, com desempenhos diferentes nas línguas em função do contexto de uso e do propósito comunicativo.

Para além de questões linguísticas, na articulação aos Estudos Surdos ${ }^{9}$, interessa refletir acerca de uma educação escolar bilíngue como uma proposta que contempla a cultura surda. A cultura surda é entendida como um modo de vida, um espaço de constituição de identidades e de comunidades que determinam a vida dos sujeitos e dos povos surdos; compreende história própria, em que se destacam aspectos coletivos, individuais, artísticos, educacionais, regras, costumes e tradições das comunidades surdas. Porém, a cultura surda não se constitui homogeneizada, cristalizada, de pureza essencial, pois cada sujeito surdo constrói sua identidade e representa a si mesmo a partir de suas experiências.

Para Lopes e Veiga-Neto (2006), cultura pode ser entendida como um conjunto de práticas capazes de serem significadas por um grupo de pessoas que vivem e sentem a experiência visual, no caso dos surdos, de uma forma semelhante. Ainda segundo esses pesquisadores, ser surdo pode ser compreendido como a possibilidade de ter uma existência construída sobre marcadores que afirmam a produtividade da diferença, a presença imperiosa do ser sobre o si que remete a subjetividades construídas e conjugadas a partir do outro surdo. Assim, pela manutenção de sua própria existência, marcadores culturais - como luta, vida em comunidade, língua de sinais, a presencialidade e a experiência do olhar- são invenções surdas pela manutenção de sua própria existência e exaltação da diferença surda.

Em vista desses marcadores, a cultura surda pode ser considerada como uma cultura visual, já que as produções linguísticas, artísticas, científicas e as relações sociais são visuais.

\footnotetext{
${ }^{9}$ Os Estudos Surdos podem ser compreendidos como "um programa de pesquisa em educação, pelo qual as identidades, as línguas, os projetos educacionais, a história, a arte, as comunidades e as culturas surdas são focalizados e entendidos a partir da diferença, a partir do seu reconhecimento político”. (SKLIAR, 2010, p. 5).
} 
Concordando com Quadros (2003), interessa estabelecer as relações de olhar (que começam na relação que os pais surdos estabelecem com os seus bebês), usar a direção do olhar para marcar as relações gramaticais, ou seja, as relações entre as partes que formam o discurso. A experiência é visual desde o ponto de vista físico (os encontros, as festas, as histórias, as casas, os equipamentos...) até o ponto de vista mental (a língua de sinais, os sonhos, os pensamentos, as ideias...). Ainda conforme essa pesquisadora, a linguagem é fundamental ao ser humano para o estabelecimento de vários tipos de relações, para a expressão do pensamento e a constituição da subjetividade; por isso, a experiência visual, embora compreenda a experiência linguística visual, não se reduz apenas ao uso da língua de sinais.

Diante desse entendimento, qualificar a educação de surdos implica possibilitar um contexto educacional mais significativo para esses sujeitos, aqui entendidos como 'diferentes' e não 'deficientes'. Concordando com Lopes (2011, p. 23), pensar o sujeito surdo significa considerar suas formas de se relacionar, de se identificar, de se distanciar, de se comunicar, de utilizar a visão como um elo aproximador entre sujeitos semelhantes; trata-se de uma experiência vivida na coletividade surda, sem, com isso, desconsiderar as singularidades desses sujeitos. Por isso, a diferença surda se dá no âmbito da cultura, sem excluir a diferença inscrita no corpo surdo. E é essa diferença que requer ser observada nas práticas pedagógicas dos docentes, não apenas - mas também - no componente curricular de Arte, privilegiando os aspectos visuais no processo de ensino/aprendizagem.

Assim,

[...] evita-se toda uma possível denúncia acerca do fracasso da instituição-escola, das políticas educacionais e da responsabilidade do Estado. O que fracassou na educação dos surdos foram as representações ouvintistas acerca do que é o sujeito surdo, quais são os seus direitos linguísticos e de cidadania, quais são as teorias de aprendizagem que refletem condições cognitivas dos surdos, quais as epistemologias do professor ouvinte na sua aproximação com os alunos surdos, quais são os mecanismos de participação das comunidades surdas no processo educativo, etc. (SKLIAR, 2010, p. 18-19).

A educação de surdos, na perspectiva aqui assumida, sugere a produção de uma política de significações que instigue a participação dos surdos no processo de escolarização. Para tal, o processo de leitura de imagens, vinculada ao ensino da arte, pode também oferecer subsídios para o desenvolvimento de uma postura mais reflexiva sobre o contexto em que os sujeitos estão inseridos. Se aprendizagem do sujeito surdo se dá sobretudo de forma visual, promover o ato de pensar sobre as imagens e a construção de saberes pelos protagonistas 
surdos também provoca os educadores, sobretudo no exercício da reflexão crítica acerca de sua prática.

Nessa perspectiva, a atividade prática de leitura de imagens, proposta em aulas de Arte, não pretendeu decodificar a imagem a ponto de uma aproximação iconológica, mesmo porque não se está realizando o trabalho de um crítico ou marchand ${ }^{10}$ de arte. Como norteadores para concretização da proposta, foram apresentadas as vias de comunicação com a obra, de modo a tornar a atividade mais significativa e prazerosa ao ser realizada. Assim, foram priorizados os aspectos formais e iconográficos das imagens, buscando relacioná-los à biografia do artista, bem como ao contexto social em que ele viveu e que foi produzida a obra. Em geral, observou-se insegurança dos estudantes na leitura de imagens, demonstrando 'medo de errar' o que 'poderia estar dado'. Muitos deles estão marcados por vivências, experiências e valores, que, ativados, servem de referência para refletir sobre a criação da obra, bem como permitem refletir sobre si mesmo enquanto sujeito.

A primeira obra apresentada aos alunos foi a reprodução da tela Os retirantes ${ }^{11}$, do artista modernista brasileiro Cândido Portinari. A partir dessa imagem, foi construída uma interpretação coletiva da turma, de modo que os alunos foram convidados a opinarem e/ou complementarem as questões que eram levantadas. A atividade gerou muita discussão sobre os aspectos sociais que o artista registrou em seu trabalho, pois, de fato, não é desconhecida a intenção de Portinari em representar a realidade brasileira em suas obras. Para tal, realizou-se uma contextualização histórica da obra, trazendo algumas considerações sobre a biografia do artista.

Ainda que essa fosse uma atividade de aquecimento, permitiu perceber singularidades em interpretações realizadas por alunos surdos, sendo que tais evidências tornaram-se mais consistentes ao longo da atividade prática. É importante ressaltar que, ao descrevermos a leitura de imagens feita por surdos e ouvintes, não propomos compará-las, muito menos indicar alguma como melhor que outra. Interessa-nos, muito mais, problematizar a contribuição dessas práticas para pensarmos a diferença surda em contextos educacionais que podem ser descritos como bilíngues.

\footnotetext{
${ }^{10}$ Palavra francesa que designa o profissional que negocia obras de arte.

${ }^{11}$ A obra é construída com várias figuras esqueléticas, que formam uma família de pessoas que abandonaram sua casa em busca de melhores condições de sobrevivência.
} 
Uma das singularidades observadas é que, em geral, os alunos surdos apresentaram uma intimidade maior no diálogo com as imagens, percebendo detalhes sobretudo em alguns pontos como mãos, pés e vestimentas. A partir dessas percepções, os surdos ativam os recursos de análise da imagem, construindo, com isso, uma leitura muito mais rica em interpretação, além de ligarem os elementos constituintes com o todo: a imagem. Considerando a temática da obra, os alunos surdos centralizaram suas análises em necessidades básicas humanas, com discussões sobre a fome, a seca, a magreza, a pobreza e o sofrimento diante da situação, ou seja, deram um enfoque para problemáticas que são da ordem da materialidade (observáveis, sentidas, vividas).

Em um encontro posterior, propôs-se a leitura de imagem de uma fotografia, em um contexto mais contemporâneo. Trata-se da fotografia do artista brasileiro Miguel Rio Branco, intitulada Amaú turn around (1983), que mostra uma criança maltrapilha em frente a uma parede cor-de-rosa, com o rosto virado para trás. Para isso, a imagem, apresentada a seguir, foi projetada na parede da sala de aula, sendo informado o nome do artista e da obra. Foi solicitado que os alunos desenvolvessem uma leitura de imagem, registrando suas percepções de modo escrito, em língua portuguesa.

Fig. 1 - MIGUEL RIO BRANCO. “Amaú turn around”, 1983.

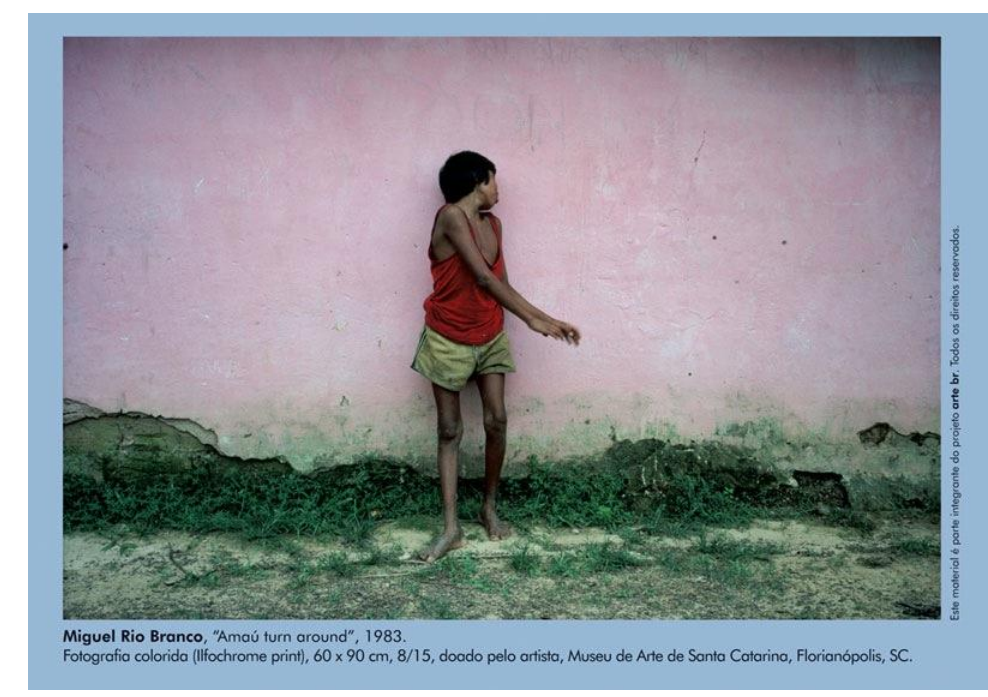

Fonte: disponível em: http://artenaescola.org.br/artebr/material/agora-eu-era.php

Os alunos surdos, novamente, focaram-se em questões de ordem física e do âmbito presente, discutindo necessidades básicas da criança mostrada na fotografia, sua família e o sofrimento que ela estaria sentindo. Os estudantes desenvolveram a leitura da imagem com destaque para a descrição do 'menino', lido como pobre, magro, sujo, solitário, triste, 
KAPPAUN, I. J; MÜLLER, J. I.; KIPPER, D.; THOMA, A. S.

abandonado, órfão; e isso é possível observar nos trechos selecionados e a seguir apresentados, em que os estudantes surdos usam a língua portuguesa, sua segunda língua, para expressarem suas percepções:

O menino é pobre, magro, sujo eu acho que esse menino não tem amigos para brincar com ele acho que ele vive sozinho no mundo e não tem o que comer isso é uma tristeza de ver esse menino pobre e quando tá frio o menino não tem roupa quente para botar isso é preciso de ajuda...

Eu acho muito triste de ver esse menino sozinho sem amigo no lado sem brincar sozinho sem fazer nada é muito ruim de ficar sozinho. (Ana)

O menino como sentido magro muito sofrimentos tristeza não tem lugar família como fome pedir ajuda não nada dinheiro. (Bruno)

O homem tem sofre muito sentir sozinho faltar não respeito amigos inimigo faltar educação olhado sentir tristeza, porque as pessoas provoca precisa respeito união. (Camila)

Um menino sozinho, não amigo não família ninguém para olhar menino.(...) Família coloca menino rua ele fica sozinho, não tem o que comer, ele fica ruas sem o que fazer e acaba fazendo só coisa ruim como roubar para poder comer e até matar, para poder sobreviver difícil ele sem ajuda de pessoas amigos sem ter para onde ir dificuldade a cada dia que passa ele transtornado entra nas drogas.(..) Muito triste, mas esta é a nossa realidade de hoje e cada ano que passa sempre mais difícil, porque ninguém respeita mais ninguém os jovens de hoje acham que podem fazer o que quiser $e$ desrespeitam seus pais, triste mas é assim a nossa realidade. (Daniela)

Além do conteúdo observado nesta leitura de imagens, importa também considerar que, nesta transcrição, respeitou-se a expressão escrita dos surdos, tendo em vista que o 
português (na modalidade escrita) é aprendido como segunda língua. Nesse sentido, interessa tensionar o caráter da proposta encaminhada na aula de Arte, ou seja, as orientações didáticas para a leitura de imagens carecem de um olhar para a diferença surda. Nesse caso, o ensino da arte deu-se em língua portuguesa e, apesar de um processo de tradução/interpretação em língua de sinais, a produção de dados foi solicitada em português para todos os alunos da turma, sem levar em conta marcas culturais surdas.

Discutindo a experiência do olhar, Caldas $(2012)^{12}$ afirma:

[...] os surdos que percebem e aprendem com os olhos, as coisas que vemos são captadas através de nossos olhos como as propagandas, manchetes, notícias, cinema, gestos, movimentos, lugares e tudo mais que está além de um simples olhar [...]. Um surdo sinaliza para outro surdo e o seu ser se manifesta, ele o faz no uso de sua linguagem visual, as mãos manifestam o ser surdo. [...] É através desta língua [a Libras] que nós, surdos, imaginamos, pensamos, expressamos nossas ideias e criamos significados com os quais, entre outras linguagens, farão com que possamos interagir com os adultos, com as crianças e com o mundo. (CALDAS, 2012, p. 142).

Isso não quer dizer que os alunos surdos não sejam capazes de ler, compreender e escrever textos na sua segunda língua, mas as práticas pedagógicas em turmas comuns do Ensino Médio, mesmo que formadas também por alunos surdos e com a participação de TILS, ainda são predominantemente pensadas e desenvolvidas na perspectiva ouvinte. Enfim, a diferença surda não parece ser considerada em ambientes escolares comumente representados como inclusivos ou entendidos como bilíngues. Essa constatação requer uma análise mais aprofundada, já que o processo de leitura de imagens em Libras dar-se-ia de outros modos; além disso, outras percepções e produções poderiam emergir das interações em língua de sinais, sobretudo entre professor e alunos.

Ainda que a aproximação dos estudantes surdos tenha se dado principalmente por uma via de acesso, a sua segunda língua, as leituras feitas apresentaram riqueza de conteúdo. Tratam-se de reflexões significativas, que apontam o comprometimento com a proposta de leitura e revelam uma aproximação do sujeito com a figura representada na imagem de referência. Uma vez que uma leitura de imagem pressupõe o vínculo das informações impressas na obra com as próprias vivências e experiências do leitor, as leituras produzidas

\footnotetext{
${ }^{12}$ Em sua dissertação de mestrado, intitulada "O filosofar da arte na criança surda: construções e saberes", Caldas (2007) analisou, a partir de experiências estéticas visuais, o 'filosofar' na arte das crianças surdas. Para isso, provocou a reflexão dos sujeitos e a vivência do olhar, trazendo suas hipóteses e compreensões sobre as pinturas. Com acesso feito em 20 março de 2015, a dissertação da pesquisadora surda está disponível no site: <https://www.lume.ufrgs.br/bitstream/handle/10183/8735/000587787.pdf?sequence=1>.
} 
revelam particularidades específicas de cada sujeito e evidenciam uma percepção diferenciada.

Nos alunos surdos, a obra suscitou um olhar para as necessidades básicas humanas, como a fome e o frio, por exemplo, de modo que, nos apontamentos sobre a imagem da criança, os estudantes voltaram-se às suas próprias vivências e sentimentos. Essa constatação é possível uma vez que se tem acesso às narrativas de vida dos estudantes surdos; aliás, frequentemente, a sala de aula e a escola são os únicos espaços em que os surdos se socializam com outros surdos ou ouvintes usuários da Libras. As experiências singulares constituem os sujeitos, e essa subjetividade produz enunciados articulados ao discurso ${ }^{13}$ de um tempo e espaço.

A leitura de imagens desenvolvida por Ana, por exemplo, mostra a sua preocupação com as relações de amizade da criança representada na imagem. Tal fator é muito significativo na vida da própria aluna, que, devido à família, foi isolada do convívio social durante muito tempo de sua vida. Vale destacar que Ana possui resquícios auditivos e é oralizada, características que geram um conflito de identidade, o que lhes causa frustração e dificuldade no estabelecimento de relações de amizade com ouvintes e/ou surdos. Bruno, por sua vez, aponta o sofrimento causado pela fome e desamparo familiar, destacando a necessidade financeira. Distante da família e administrando sozinha as finanças mensais, acaba ficando sem dinheiro durante o mês, fazendo que o mesmo frequente a escola em busca da merenda oferecida. Tais preocupações rotineiras de Bruno estão marcadas nas interpretações das imagens, sobretudo quando expressa não haver 'lugar na família' e precisar 'pedir ajuda e dinheiro'.

Esses exemplos, entre outros, revelam muito mais que a simples reflexão sobre uma figura esquelética que parece se esconder diante de uma parede cor-de-rosa. O que se evidencia é a transposição de si mesmo para o lugar da criança representada na fotografia: seu rosto virado é carregado de significado, trazendo consigo uma história de opressão, discriminação e desrespeito. Ativar esses recursos desacomoda e perturba! A reflexão na leitura de imagens desencadeou uma série de associações, vivências, memórias, perspectivas e desejos de sujeitos que, por vezes, não se sentem pertencentes a lugar algum. Por isso, e

\footnotetext{
${ }^{13}$ Discursos são entendidos como práticas sociais que constituem e significam as coisas do mundo; não mais tratados somente como um conjunto de signos (elementos significantes que remetem a conteúdos ou a representações), mas como práticas que formam sistematicamente os objetos de que falam (FOUCAULT, 2002).
} 
também talvez devido ao uso de uma segunda língua na docência, algumas informações ligadas aos aspectos formais das obras pareceram irrelevantes aos sujeitos surdos envolvidos nesta prática investigativa.

Neste contexto, as vias de acesso à obra de arte apresentadas por Trevisan (1990), revelam-se não somente como canais de comunicação com a obra, mas como vias de acesso ao sujeito surdo. A leitura de imagens possibilita a constituição de uma nova obra, pois o leitor é protagonista, na articulação entre obra, artista e fruidor. Não é mais um diálogo entre a obra e o leitor da imagem, separados por tempos e lugares diferentes. A experiência de si oportuniza que o sujeito olhe para si, refletiva, julgue-se e se produza. Nesse movimento, há que se considerar não apenas a diferença surda em relação à visualidade, mas também as singularidades que nos constituem únicos e incompletos.

Se o mais significativo na arte e na leitura da mesma está em sensibilizar o fruidor e, ao mesmo tempo, afastá-lo de sua zona de conforto, parece-nos que a arte e seu ensino escolar cumprem seu propósito: desacomodar, provocar reflexões, questionar e duvidar de verdades instituídas. A leitura de imagens nas aulas de Arte, para além do propósito de conhecer estilos artísticos, biografias de artistas ou técnicas e materiais empregados para a produção de uma obra artística, predispõe-se a não mais perpetuar paradigmas sociais. Assim, as subjetividades dos leitores surdos possibilitam uma construção de si e do outro, ou seja, a arte pode ser compreendida como mais uma promissora vertente de possibilidades e de reflexões. Além disso, a visualidade na leitura de imagens, na aproximação à Arte-Educação, adquire caráter de centralidade na educação de surdos, independentemente do componente curricular ou área de conhecimento, como discutiremos a seguir.

\section{LINGUAGEM VISUAL: CAMINHOS POSSÍVEIS}

Ler imagens permite a elaboração de questionamentos que se lançam para além de reflexões estéticas, ou seja, provoca um repensar de padrões e concepções pré-formadas, ideais consagrados e problemáticas do mundo contemporâneo. Desse modo, o estudo da leitura de imagens contribui para análise e conhecimento das diferenças, possibilitando uma reflexão sobre os atuais processos educacionais e problemas sociais. Oportunizar aos alunos a reflexão sobre si e o contexto em que vivem é importante no desenvolvimento de uma proposta de ensino, não apenas - mas também - na disciplina de Arte. 
Em geral, um dos desafios maiores da educação é atender às necessidades dos alunos, propiciando construções significativas a partir das diferenças. No caso dos surdos, a comunicação se dá principalmente através da língua de sinais e de uma linguagem visual; logo, a aprendizagem deles não poderia ser por meio de outra via, o que vai ao encontro das movimentações que defendem uma educação escolar bilíngue. Em virtude disso, importa propor um trabalho com professores bilíngues, tomando a visualidade como ponto central no processo ensino/aprendizagem. Segundo Rodrigues e Quadros (2015), a visão potencializa aspectos do humano; logo, as diferenças surdas favorecem ganhos surdos efetivos, os quais trazem significativas implicações à educação.

Pensar em uma política pelas diferenças exige um olhar mais atento às especificidades e suas implicações. Mudanças profundas requerem a participação política das pessoas surdas para nos apontar o que significam as diferenças e como elas precisam ser consideradas no currículo. A experiência visual, muitas vezes, relegada a um segundo ou terceiro plano, deve passar a ser o centro das atenções, pois ela é a base do pensamento e da linguagem dos surdos. (QUADROS, 2003, p. 102)

Muito mais que propor soluções, em vista de uma atividade prática desenvolvida em turmas comuns do Ensino Médio, neste texto, buscamos refletir sobre um possível modo de pensar o ensino da arte e a educação escolar de surdos. Para isso, não discutimos a inclusão escolar, muito menos comparamos estudantes surdos e ouvintes, que estudam em uma mesma turma. De qualquer modo, desafios compõem o cenário da educação escolar bilíngue, em constante processo de construção.

Nesse cenário de investimentos na inclusão escolar, por um lado, e de afirmação da diferença e da cultura surda que se mobiliza e luta por uma educação bilíngue, que desafios são colocados para as escolas e para o currículo? [...] Sendo o currículo entendido como um artefato que produz sujeitos, tanto na escola bilíngue como na escola comum serão produzidos modos de ser surdo. (THOMA, 2012, p. 211)

Nos diferentes modos de produção do sujeito surdo, na escola bilíngue ou na escola comum, reiteramos a importância da linguagem visual. Como docentes e pesquisadores, convém realizar uma leitura de nós mesmos, de nossas práticas, dos discursos que instituímos, dos modos pelos quais posicionamos os outros. Enfim, a proposta aqui analisada desperta questionamentos, desacomoda docentes e pesquisadores, tensiona verdades, aguça a curiosidade e fomenta práticas futuras, as quais atentam principalmente para a singularidade linguística e cultural dos sujeitos surdos. 


\title{
IMAGE READING IN ART: A LOOK FOR THE DEAF EDUCATION
}

\begin{abstract}
This paper proposes a reflection about the image reading performed by deaf people, who study at a common class of the $2^{\text {nd }}$ High School, in a public school of Santa Cruz do Sul/RS. In conjunction with Deaf Studies and Art Education, it problematize implications of deaf visual experience in school education, with a view to observing a practical activity, in which assigns meaning to artistic images through the 'Triangular Proposal for Teaching Art' (BARBOSA, 1991). Designed in the discipline of Art and mediated by translators and sign language interpreters, the activity carried out provided an opportunity to approach the students to imagery object and its context. Considering the deaf identities, there is evidence of an image reading process that builds on the visual and the unique experiences of each subject in the construction of meanings. In art and in deaf education, the visual language is central.
\end{abstract}

Keywords: Deaf; Image reading; Visual Language. Art Education; Deaf Studies

\section{LECTURA DE IMÁGENES EN ARTE: UNA MIRADA PARA LA EDUCACIÓN DE SORDOS}

\section{Resumen}

Este trabajo propone una reflexión sobre la lectura de imágenes realizada por sujetos sordos, que estudian en una clase común del $2^{\circ}$ año de la Enseñanza Mediana, en una escuela pública de Santa Cruz do Sul/RS. En la articulación a los Estudios Sordos y a el Arte-Educación, se problematizan las implicaciones de la experiencia visual sorda en la educación escolar, teniendo en cuenta la observación de una actividad práctica, en la cual se atribuye significado a imágenes artísticas por medio de la "Propuesta Triangular de Enseñanza de Arte" (BARBOSA, 1991). Desarrollada en la asignatura de Arte y mediada por traductores e intérpretes de la lengua de señas (TILS), la actividad realizada ha permitido la aproximación de los alumnos al objeto imaginario y su contexto. Considerándose las diferencias sordas, se 
KAPPAUN, I. J; MÜLLER, J. I.; KIPPER, D.; THOMA, A. S.

evidencia un proceso de lectura de imágenes que se basa en lo visual y en las experiencias singulares de cada sujeto en la construcción de significados. En arte y en educación de sordos, el lenguaje visual asume centralidad.

Palabras clave: Sordos; Lectura de Imágenes; Lenguaje Visual; Arte-educación; Estudios Sordos

\section{REFERÊNCIAS}

BARBOSA, Ana Mae. A imagem no ensino da arte: anos oitenta e novos tempos. São Paulo: Perspectiva; Porto Alegre: Fundação IOCHPE, 1991.

BARBOSA, Ana Mae. Inquietações e mudanças no ensino da arte. São Paulo: Cortez, 2002.

BRANCO, Miguel Rio. Amaú turn around. 1983. Disponível em: http://artenaescola.org.br/artebr/material/agora-eu-era.php. Acesso em 15 mar. 2015.

CALDAS, Ana L. P. Movimento surdo: identidade, língua, cultura. In: PERLIN, Gládis; STUMPF, Marianne (org.) Um olhar sobre nós surdos: leituras contemporâneas. Curitiba, PR: Editora CRV, 2012.

CALDAS, Ana L; P. O filosofar da arte na criança surda: construções e saberes. Porto Alegre: UFRGS, 2007. 123 f. Dissertação (Mestrado), Programa de Pós-Graduação em Educação, Faculdade de Educação. Universidade Federal do Rio Grande do Sul, Porto Alegre, 2007.

FOUCAULT, Michel. A Arqueologia do Saber. Rio de Janeiro: Forense Universitária, 2002.

KARNOPP, Lodenir B. Educação bilíngue para surdos: ao que estamos sinalizando? In: FREITAS, Débora; CARDOZO, Sandra (Org.). (In)formando e (Re)construindo Redes de Conhecimento. Boa Vista: UFRR, 2012. v. 1.

LOPES, Maura C. Surdez \& Educação. 2. ed. rev. e ampl. Belo Horizonte: Autêntica, 2011.

LOPES, Maura Corcini; VEIGA-NETO, Alfredo. Marcadores Culturais surdos: quando eles se constituem no espaço escolar. Perspectiva - Dossiê Língua de Sinais e Educação de Surdos. V.24, n. Especial - jul / dez. UFSC /CED, Florianópolis, 2006, p.81-100. Disponível em <:http://www.perspectiva.ufsc.br/perspectiva_2006_especial/04_Maura_e_Alfredo.pdf>

OLIVEIRA, Sandra R. Imagem também se lê. São Paulo: Edições Rosari, 2005. 
PERLIN, Gládis Taschetto. O lugar da cultura surda. In: THOMA, Adriana da Silva; LOPES, Maura Corcini (Org.). A invenção da surdez: cultura, alteridades, identidade e diferença no campo da educação. Santa Cruz do Sul: EDUNISC, 2004.

RODRIGUES, Carlos H.; QUADROS, Ronice M. de. Diferenças e linguagens: a visibilidade dos ganhos surdos na atualidade. Revista Teias (UERJ), v. 16, p. 72-88, 2015.

QUADROS, Ronice M. de. Situando as diferenças implicadas na educação de surdos: inclusão/exclusão. Ponto de Vista (UFSC). Florianópolis, SC, n.05, p. 81-11 1, 2003.

SANTAELLA, Lucia. Semiótica aplicada. São Paulo: Cengage Learning, 2002

SKLIAR, Carlos (org.). A surdez: um olhar sobre as diferenças. Porto Alegre: Mediação, 2010. (4. Ed. atual. Ortog.).

STROBEL, Karin. As imagens do outro sobre a cultura surda. Florianópolis: Ed. da UFSC, 2009.

THOMA, Adriana da Silva. A afirmação da diferença e da cultura surda no cenário da educação inclusiva: desafios para o currículo. In: SARAIVA, Karla; MARCELLO, Fabiana de Amorim. (Org.). Estudos Culturais e Educação: desafios atuais. 1ed. Canoas: Ulbra, 2012.

TREVISAN, Armindo. Como apreciar a arte. Porto Alegre: Mercado Aberto, 1990.

VEIGA-NETO, A. Michel Foucault e os Estudos Culturais. In: COSTA, Marisa (Org.). Estudos culturais em educação. Porto Alegre: Ed. Universidade/UFRGS, 2000.

Data de recebimento: 30/03/2015

Data de aceite: 03/09/2015 